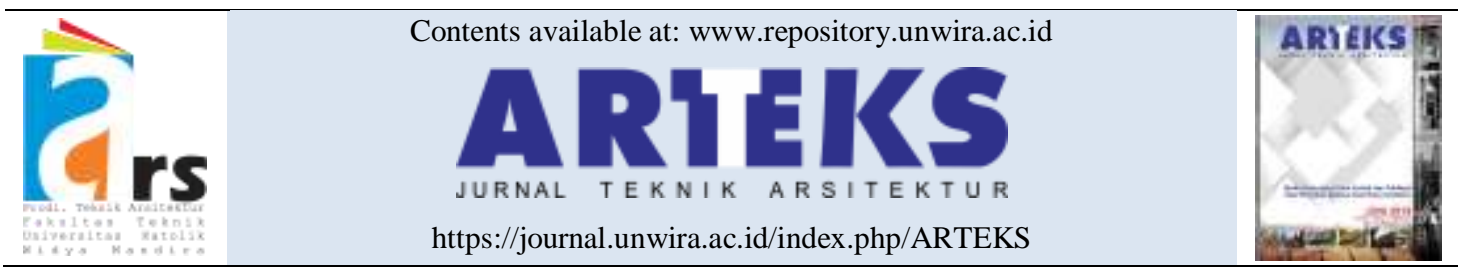

Research paper

doi: $10.30822 /$ arteks.v6i3.876

\title{
Role of physical elements in the image formation of a creative city Case study of Pekalongan Batik City
}

\author{
Edy Abdurrahman Syahrir, Retno Widodo Dwi Pramono* \\ Urban and Regional Planning, Faculty of Engineering, Universitas Gadjah Mada \\ Jl. Grafika, no. 2, Yogyakarta, 55281, Indonesia
}

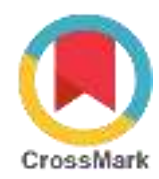

\begin{tabular}{|c|c|}
\hline ARTICLE INFO & ABSTRACT \\
\hline $\begin{array}{l}\text { Article history: } \\
\text { Received January 06, } 2021 \\
\text { Received in revised form Jan. 24, } 2021 \\
\text { Accepted Sep. 11, } 2021 \\
\text { Available online December } 01,2021\end{array}$ & $\begin{array}{l}\text { Several creative cities aim at becoming tourist destinations, due to } \\
\text { the support of physical elements supported by visual identity. } \\
\text { Furthermore, due to the low number of tourist visits, most cities have } \\
\text { optimally embraced creativity during development, thereby making } \\
\text { it a driving force for its citizens' welfare. Therefore, this research }\end{array}$ \\
\hline $\begin{array}{l}\text { *Corresponding author: Retno Widodo } \\
\text { Pramono } \\
\text { Urban and Regional Planning, Faculty of } \\
\text { Engineering, Universitas Gadjah Mada, } \\
\text { Indonesia } \\
\text { Email: pramono.wid@ ugm.ac.id } \\
\text { ORCID: https://orcid.org/0000-0003-4070- } \\
\text { 5550 }\end{array}$ & $\begin{array}{l}\text { aims to identify the physical elements as associated with the image } \\
\text { formation of Pekalongan City based on the assessments of residents } \\
\text { and visitors. This is a deductive research with the quantitative and } \\
\text { qualitative method used for analysis and data were obtained from } \\
\text { primary and secondary sources. Primary data were collected } \\
\text { through observation, questionnaires, and interviews, while } \\
\text { secondary were obtained from literature studies and content } \\
\text { searches on the internet. The results showed that the design of a } \\
\text { city's physical element through cultural works and folk arts, create } \\
\text { unique attributes that attract tourists. Furthermore, these results are } \\
\text { expected to encourage city planners and designers to help city } \\
\text { managers to understand the importance and uniqueness of visual } \\
\text { image for branding formation in an effort to strengthen its } \\
\text { competitiveness and attract tourists. }\end{array}$ \\
\hline
\end{tabular}

\section{Introduction}

The creative economy is associated with the generation or exploitation of knowledge and information. This has become the basis for city development, especially with its high added value and multiplier effect on the tourism sector. According to the Indonesian Ministry of Trade (2008), the creative economy is an effort to develop a sustainable city through creativity in accordance with a competitive economic climate. Manisyah (2009) stated that any place that has been successfully developed based on a creative economy is referred to as a creative city. Furthermore, Landry and Bianchini (1995) specifically defined a creative city as a place with unique people that carry out various activities creatively. Therefore, such cities are identified by (1) Developing potential and creative economy,
(2) Maintaining a creative class, and (3) Having a plan and development towards the realization of a creative environment (Landry 2006; Bawole 2020; Purbadi and Lake 2019).

One of the cities in the world that has succeeded in making the creative economy sector its powerhouse is Duran, located in Ecuador. The excellence of this city is based on the ability to embrace creativity. In addition, its culture serves as a driving force for the welfare of the citizens. This was realized by developing a relationship between modern creative fields and local folk arts (Sawe 2017). In Indonesia, this sector was also promoted by implementing various policies, such as preparing incentives to bolster the development of culture-based creative industries, designing an innovative roadmap by involving the government and private sector, developing programs to drive the creative economy, providing legal protection, 
incentives and facilities for creative industry work, and actors Ministry of Tourism and Creative Economy (2018). According to the survey data obtained from the Central Statistics Agency (2016), the GDP of this sector from 2010 to 2015 increased from 525.96 trillion to 852.24 trillion, which is equivalent to an average yearly rise of $10.14 \%$.

The United Nations Educational Scientific and Cultural Organization (UNESCO) stated that Pekalongan, Bandung, and Ambon are creative cities with the intension of becoming tourist destinations. However, they are not supported by visual identity as an image-forming element (Anshori 2019). According to Lestari (2016), Adona, Nita, and Mafrudoh (2017), and Ziyaee (2018), the visual identity is the branding process used to build a distinctive city image in order to differentiate it from others and make it a tourist attraction center (Saputri, Fauzi, and Irawan 2018; d'Ovidio and Cossu 2017; Puspitasari 2016).

On December 1, 2014, Pekalongan was named the World Creative City in Craft and Folk Arts by UNESCO. Latifah and Damayanti (2016) reported that the identity-formation in this city is mostly obtained by non-physical aspects in the form of creative tourism activities and the batik industry. Furthermore, the physical components' existence plays an important role in forming the city's visual identity and its life system (Budiman, Rondonuwu, and Tungka 2018; Hilman and Megantari 2018). Unfortunately, continuous growth in this condition in the long term tends to hamper the branding of Pekalongan as a Creative City.

Therefore, to economically support this city's optimal development, it is necessary to carry out research that understands the processes and elements relevant for the formation of the physical visual identity. This understanding is expected to become the foundation for organizing and designing the physical components needed in a creative city. Therefore, this research tries to determine how the image level of Pekalongan is perceived by the wider community and the contribution of the city's physical visual elements to its image formation.

\section{Method}

\section{Data collection}

The ability to determine whether Pekalongan is known as batik or creative city is carried out in 2 ways. Firstly, by recognizing and measuring the popularity attribute in cyberspace, and secondly through questionnaires distributed among members of the local community and tourists.

Furthermore, to determine its popularity, the internet contents associated with the city were analyzed. This method is logically used to identify trending news regarding this area on electronic media. The search was carried out using the following keywords, Kota Batik (Batik City, Batik Region, Batik Society), and Kota Kreatif Batik (Batik Creative City). The more often Pekalongan City appears as a search result or is reported using these keywords, the stronger its identity as a popular Batik or Creative City. The number of occurrences is compared to other cities with similar keywords. These led to a ranking related to the identity strength at the community level. Furthermore, the keywords "Kota Pekalongan (Pekalongan City)" is often to analyze the term Kota Batik, or Kota Kreatif Batik, on websites associated with Pekalongan City.

Questionnaires were distributed among the local community and tourists to obtain data related to identity strength. The 130 respondents were selected through purposive nonprobability sampling technique, based on the following criteria, such as the need to be an indigene of the local community and tourists that have or are currently traveling to Pekalongan City.

The questionnaire contains questions regarding significant physical elements, which are the main characteristics of Pekalongan as Batik, or Creative City. These questions are compiled from the results of the elaborated literature deduction. Therefore, it is separately used to identify the physical elements which shape the respondents' perceptions of Pekalongan as a Batik, or Creative City.

Based on the theoretical deduction results, the questionnaire contains seven variables of the physical elements, as shown in table 1. 
Table 1. Elaboration of city visual element variable

\begin{tabular}{lllll}
\hline No & Total site findings & Theory source & $\begin{array}{l}\text { Keywords asked the } \\
\text { respondents }\end{array}$ & $\begin{array}{l}\text { Local forms/terms cited as } \\
\text { examples }\end{array}$ \\
\hline 1 & District & $\begin{array}{l}\text { Lynch 1960, Shirvani 1985, } \\
\text { Trancik 1986 }\end{array}$ & Block & Village area \\
\hline 2 & $\begin{array}{l}\text { Path (transportation } \\
\text { network) }\end{array}$ & $\begin{array}{l}\text { Lynch 1960, Shirvani 1985, } \\
\text { Trancik 1986 }\end{array}$ & $\begin{array}{l}\text { Highway, pedestrian, } \\
\text { and bicycle paths }\end{array}$ & Highway, sidewalk \\
\hline 3 & Street furniture & Shirvani 1985, Trancik 1986 & Road facilities & $\begin{array}{l}\text { Pedestrian paths, street lights, } \\
\text { bus stops, traffic signs, shade } \\
\text { plants, chairs }\end{array}$ \\
\hline 4 & Edges & Lynch 1960, Trancik 1986 & City limits & River, railroad cut, highway \\
\hline 5 & Preservation & $\begin{array}{l}\text { Lynch 1960, Shirvani 1985, } \\
\text { Trancik 1986 }\end{array}$ & Historical legacy & Ancient buildings \\
\hline 6 & Landmark/icon & $\begin{array}{l}\text { Lynch 1960, Shirvani 1985, } \\
\text { Trancik 1986 }\end{array}$ & Monument or icon & Monument, building \\
\hline 7 & Open space & Shirvani 1985, Trancik 1986 & Garden & Square, field \\
\hline
\end{tabular}
Source: (Lynch 1960; Shirvani 1985; Trancik 1986)

The technique used to analyze the image popularity level of Pekalongan as batik and creative city was based on the internet search results, which compared its popularity with other cities. Therefore, to assess the extent of its popularity, the news area's coverage level was utilized in a hierarchical order from local, regional, national to international scales. Although each level has a score, the popularity of Pekalongan City's identity at the international level was based on the highly scored percentage, which rapidly increased.

The identity strength was measured in realtime using a questionnaire, requesting the local community respondents and tourists to rate the Pekalongan City's popularity as a Batik Creative area. Furthermore, the questionnaire also contained questions on respondents' physical elements in assessing the city's image. Their responses were analyzed by comparing the scoring results of the percentage values obtained from each physical element, based on descriptive statistics. Additionally, the analysis results were used to identify the highest score elements in the very strong category. These elements are regarded as the main characteristics of identity due to their significant contributions to the city identity formation measured in the real world.

Furthermore, this was carried out to recognize the variety of physical elements and their strengths in forming identities based on the respondent's questionnaire. The assessment of each element was carried out using a 1 to 3 Likert scale approach. Each score was awarded based on the criteria that served as a reference in the assessment. The scoring hierarchy is shown in table 2.

Table 2. The classification determination of the physical component attribute strength levels

\begin{tabular}{|c|c|c|c|}
\hline Score & Classification & $\begin{array}{l}\text { If the elements forms Batik City } \\
\text { identity }\end{array}$ & $\begin{array}{l}\text { If the elements forms Batik Creative City } \\
\text { identity }\end{array}$ \\
\hline 3 & Very strong & $\begin{array}{l}\text { If the respondent thinks that the } \\
\text { existence of physical elements in } \\
\text { question is the main characteristic of } \\
\text { Pekalongan as a Batik City }\end{array}$ & $\begin{array}{l}\text { If the respondent thinks that the existence of } \\
\text { physical elements in question is the main } \\
\text { characteristic of Pekalongan as a Creative City } \\
\text { with Batik commodities }\end{array}$ \\
\hline 2 & Quite strong & $\begin{array}{l}\text { If the respondent thinks that the } \\
\text { existence of the physical elements in } \\
\text { question is a characteristic, although } \\
\text { not the main one of Pekalongan as a } \\
\text { Batik City }\end{array}$ & $\begin{array}{l}\text { If the respondent thinks that the existence of the } \\
\text { physical elements in question is a characteristic, } \\
\text { although not the main one, of Pekalongan as a } \\
\text { Creative City with Batik commodities }\end{array}$ \\
\hline 1 & Not strong & $\begin{array}{l}\text { If the respondent thinks that the } \\
\text { existence of the physical elements in } \\
\text { question does not characterize } \\
\text { Pekalongan as a Batik City }\end{array}$ & $\begin{array}{l}\text { If the respondent thinks that the existence of the } \\
\text { physical elements in question does not } \\
\text { characterize Pekalongan as a Creative City with } \\
\text { Batik as the main commodities }\end{array}$ \\
\hline
\end{tabular}




\section{Result and discussion}

Pekalongan City popularity as a batik creative city in cyberspace
Table 3 and figure diagram 1 show a recap of the search results on the internet using the keyword Kota Batik (Batik City, Batik Region, Batik Society) without mentioning Pekalongan City and Kota Kreatif Batik (Batik Creative City) without including Pekalongan.

Table 3. Recapitulation percentage of the Pekaolongan City identity search results on the internet

\begin{tabular}{|c|c|c|c|c|c|}
\hline \multirow{2}{*}{ Keyword } & \multirow{2}{*}{$\begin{array}{l}\text { Total site } \\
\text { findings }\end{array}$} & \multicolumn{3}{|c|}{$\begin{array}{l}\text { Site findings containing Pekalongan } \\
\text { City }\end{array}$} & \multirow{2}{*}{$\begin{array}{l}\text { The occurrence } \\
\text { of Pekalongan } \\
\text { City }\end{array}$} \\
\hline & & Total & $\begin{array}{l}\text { Internal } \\
\text { source }\end{array}$ & $\begin{array}{l}\text { External } \\
\text { source }\end{array}$ & \\
\hline Kota Batik (Batik city, batik region, batik society) & 317.000 & 186.000 & 77.300 & 108.700 & $59 \%$ \\
\hline Kota Kreatif Batik (Batik creative city) & 402.000 & 129.000 & 51.273 & 77.727 & $32 \%$ \\
\hline
\end{tabular}

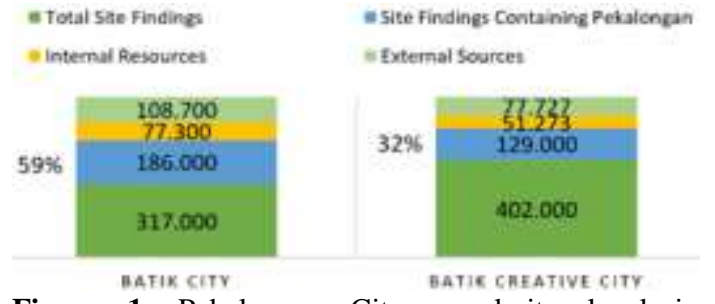

Figure 1. Pekalongan City popularity level in cyberspace

Based on the calculated results, it was understood that Pekalongan is quite popular in cyberspace and known as the Batik or Creative City. In addition, it is also dominant in the batik industry world with a percentage of $59 \%$, while $32 \%$ indicates that it is a Batik Creative City. It is also regarded as a city based on the creative economy. However, when this condition is searched using only the Creative City keyword, few findings directly related to Pekalongan City was discovered.

The popularity level of Pekalongan City's image a Batik Creative City

Based on the questionnaires distributed to 130 respondents consisting of 85 members of the local community and 45 tourists regarding the perception of Pekalongan City's image as a Batik Creative City, $59 \%$ of the locals and $44 \%$ of tourists stated that the popularity level is at the regional, national and global scale as shown in figure 2 .

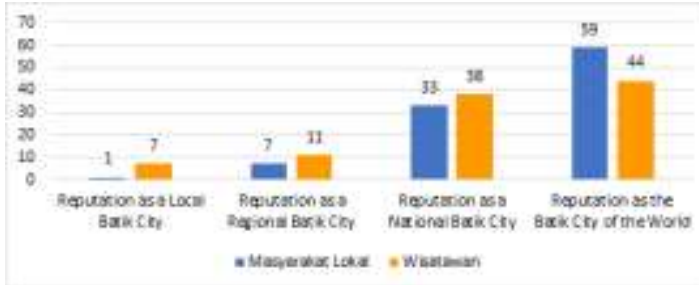

Figure 2. The popularity level of Pekalongan City as a Creative City

Ranking of the image forming elements on Batik City and Batik Creative City

This study intends to measure 7 physical elements or variables based on the deduction of city form and design theory used to identify the main characteristic features of the Pekalongan image as a Batik and Creative City. The elements scored on a Likert scale of 1 to 3 percent are tabulated in a diagram for easy in-depth analysis. In accordance with the identification results of the 7 physical elements analyzed, only 4 significant areas characterized it as Batik and Creative City based on the results of its ranking aggregation. The ranking sequence of the 4 physical elements that characterize it as a Batik City includes (1) preservation, (2) landmarks, (3) open spaces, and (4) districts. Meanwhile, the following characterized it as a Creative city (1) landmarks, (2) preservation, (3) districts, and (4) open spaces. The physical elements from the deduction of the naming theory are adjusted to the scientific city form and design, although each has more detailed objects that are easily understood by the public.

Table 4. Percentage of respondents' answers on the strength of identity forming elements

\begin{tabular}{|c|c|c|c|c|c|c|c|c|c|c|c|c|c|c|c|c|}
\hline \multirow{3}{*}{$\begin{array}{c}\text { Variable } \\
\text { (analysis } \\
\text { unit) }\end{array}$} & \multicolumn{8}{|c|}{ Perception as the Batik City } & \multicolumn{8}{|c|}{ Perception as the Batik Creative City } \\
\hline & \multicolumn{3}{|c|}{ Community } & \multicolumn{3}{|c|}{ Tourist } & \multirow{2}{*}{$\begin{array}{l}\text { Total } \\
\text { score }\end{array}$} & \multirow{2}{*}{ Rank } & \multicolumn{3}{|c|}{ Community } & \multicolumn{3}{|c|}{ Tourist } & \multirow{2}{*}{$\begin{array}{l}\text { Total } \\
\text { Score }\end{array}$} & \multirow{2}{*}{ Rank } \\
\hline & SK & CK & TK & SK & CK & TK & & & SK & CK & TK & SK & CK & TK & & \\
\hline District & 40 & 37 & 8 & 20 & 17 & 8 & 304 & 4 & 39 & 35 & 11 & 22 & 19 & 4 & 306 & 3 \\
\hline
\end{tabular}




\begin{tabular}{|c|c|c|c|c|c|c|c|c|c|c|c|c|c|c|c|c|}
\hline \multirow{3}{*}{$\begin{array}{c}\text { Variable } \\
\text { (analysis } \\
\text { unit) }\end{array}$} & \multicolumn{8}{|c|}{ Perception as the Batik City } & \multicolumn{8}{|c|}{ Perception as the Batik Creative City } \\
\hline & \multicolumn{3}{|c|}{ Community } & \multicolumn{3}{|c|}{ Tourist } & \multirow{2}{*}{$\begin{array}{l}\text { Total } \\
\text { score }\end{array}$} & \multirow{2}{*}{ Rank } & \multicolumn{3}{|c|}{ Community } & \multicolumn{3}{|c|}{ Tourist } & \multirow{2}{*}{$\begin{array}{l}\text { Total } \\
\text { Score }\end{array}$} & \multirow{2}{*}{ Rank } \\
\hline & SK & CK & TK & SK & CK & TK & & & SK & CK & TK & SK & CK & TK & & \\
\hline Path & 30 & 47 & 8 & 17 & 24 & 4 & 295 & 5 & 6 & 11 & 68 & 7 & 27 & 11 & 194 & 7 \\
\hline $\begin{array}{l}\text { Street } \\
\text { furniture }\end{array}$ & 20 & 50 & 15 & 16 & 23 & 6 & 275 & 6 & 4 & 68 & 13 & 8 & 36 & 1 & 258 & 5 \\
\hline Edges & 18 & 45 & 22 & 10 & 10 & 25 & 241 & 7 & 20 & 18 & 47 & 9 & 9 & 27 & 215 & 6 \\
\hline Preservation & 68 & 15 & 2 & 26 & 16 & 3 & 349 & $\mathbf{1}$ & 44 & 37 & 4 & 27 & 13 & 5 & 322 & 2 \\
\hline Landmark & 59 & 21 & 5 & 33 & 11 & 1 & 346 & 2 & 68 & 15 & 2 & 32 & 12 & 1 & 357 & 1 \\
\hline Open space & 53 & 29 & 3 & 26 & 15 & 4 & 332 & 3 & 48 & 5 & 32 & 27 & 17 & 1 & 302 & 4 \\
\hline
\end{tabular}

Assessment of image forming elements as Batik City and Batik Creative City

The questionnaire discovered that objects were used to represent elements, namely the district, path, street furniture, edges, preservation, landmarks, and open spaces, as reported by the respondents. The distribution of these objects is shown on the following map.

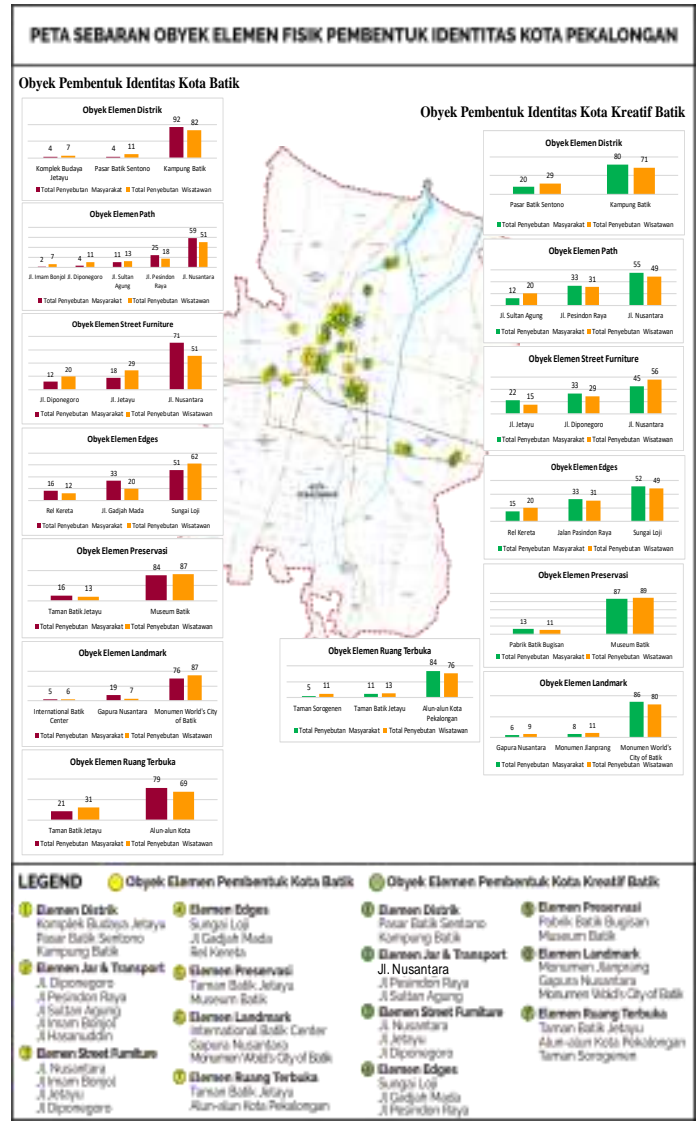

Figure 3. Map of the physical elements object distribution

\section{1) District element}

District elements in Pesindon and Kauman Batik Villages are identified as strong perceptions in shaping the Pekalongan image as a Batik and Creative City. Furthermore, 93\% of the local community respondents and $82 \%$ of tourists reported that this object is a characteristic of the Batik City identity. Meanwhile, $80 \%$ of the local community respondents and $71 \%$ of tourists characterized it as a Creative City.

The interviews carried out with several respondents, showed that the Pesindon and Kauman Batik Villages had strong impression due to the attachment of the term "batik". Secondly, the larger communities recognized the two villages as centers for batik craftsmen, with 31 production houses in Pesindon and 24 in Kauman. These two batik centers have become tourist destinations. Many tourists are also interested in witnessing the traditional process of Batik production in the district daily. Although Kauman Village does not include batik in the pronunciation, it is still regarded as a popular tourist destination. This is because it is the oldest batik producing village. Therefore, its existence creates an extremely strong impression to support the strengthening of the batik image in Pekalongan City.

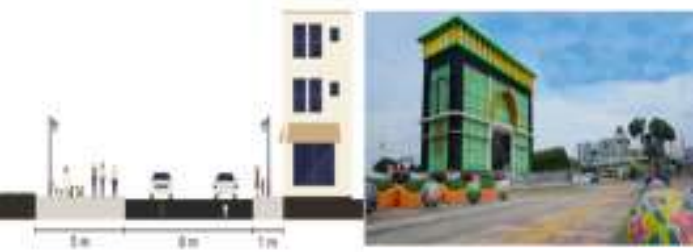

Figure 4. District situation of Kauman and Pasindon Batik Village

These two villages have better popularity than the Jetayu Cultural Complex and the Setono Batik Market, which are regarded on a national scale as cultural heritage and batik shopping center objects. The loss of the two district objects' popularity, which plays an important role in the production and marketing chain, is because the Jetayu Cultural Complex relies on seasonal activities in developing the batik city image. 
Meanwhile, the Setono Batik Market has a fairly good reputation due to its location in the suburban area, which makes its existence less prominent than Pesindon and Kauman Batik Villages in characterizing their batik images.

As districts, the Jetayu Cultural Complex and the Setono Batik Markets are still classified as strong image forming elements of the Batik City compared to the path, street furniture, edges, preservation, landmarks, and open spaces. This is because the two districts have a strong relationship due to their cultural activities and batik marketing, thereby leading to their ability to form a batik city image compared to the other physical elements.

\section{2) Path and street furniture elements}

The Nusantara Street object is strongly perceived to represent the path element in forming the Batik City and the Batik Creative City image in Pekalongan. Moreover, approximately 59\% of the local community respondents and relatively $51 \%$ of tourists reported that this object is a characteristic of the Batik City identity. Meanwhile, $55 \%$ of the local community respondents and relatively $49 \%$ of tourists stated that it is a characteristic of the Batik Creative City identity.

Meanwhile, the results were confirmed through observation, the roads are completely designed, with batik-patterned dominance attributes. Therefore, this condition creates attractiveness and a strong impression on the public regarding the Pekalongan image as a Batik and Creative City.

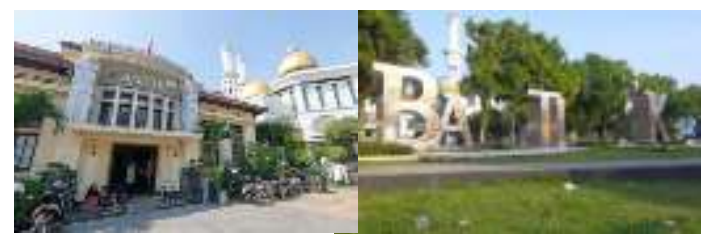

Figure 5. Cross-section of roads and empirical conditions of Nusantara Streets

The road facilities on Nusantara Street, which includes the availability of pedestrian paths, street lights, and bollards with batik motifs, are strongly identified as an image forming element of Pekalongan as a Batik and Creative City. Subsequently, $71 \%$ of respondents from the local community and $51 \%$ of tourists stated that these objects characterize the Batik City identity. Meanwhile, $45 \%$ of the local community respondents and $49 \%$ of tourists stated that the objects on this street are used in characterizing the Batik Creative City identity.

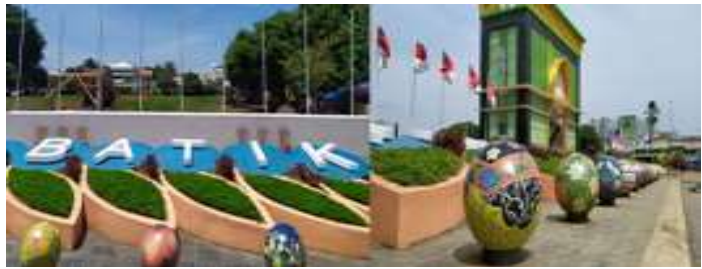

Figure 6. Facility attribute object on Nusantara Street

The popularity of Nusantara Street, with its fairly distinctive batik-nuanced facilities, creates a good impression compared to Diponegoro and Jetayu Streets, which constitutes the main roads and connecting strategic locations in Pekalongan as well as used in characterizing the Batik City identity. This is because the arrangement of designs and facilities on the two streets are classified as incomplete and lack the batik nuances, thereby giving out a fairly strong impression than the objects found in Nusantara.

\section{3) Edges elements}

Loji River represents strong edge forming elements in identifying the Pekalongan image as a Batik and Creative City. Consequently, approximately $51 \%$ of the local community respondents and $62 \%$ of tourists stated that this object is a characteristic of Batik City's identity. Meanwhile, in characterizing the Batik Creative City identity, $52 \%$ of the local community respondents and $49 \%$ of tourists mentioned the Sungai Loji. According to several respondents, the Loji River displays an appropriate impression. Firstly, its flow stretches to the Pekalongan City from north to south, serves as a barrier or trading route to several areas such as the Jetayu Old City. Secondly, it flows through strategic areas, namely the Batik Museum, Bugisan Batik Factory, as well as Pesindon and Kauman Batik Villages, therefore it exhibits a proper impression.

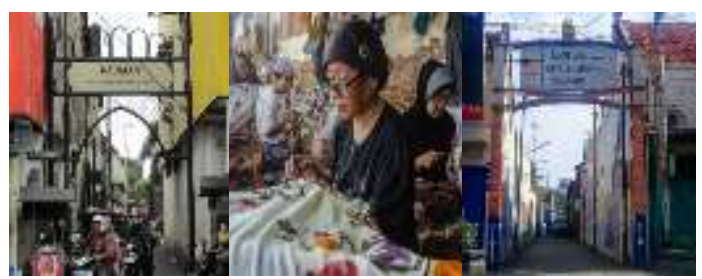

Figure 7. Existing condition of the Loji River object Source: (Innayah 2018) 
The Loji River's existence tends to create a properly emphasized popularity compared to Gadjah Mada Street, which is also one of Pekalongan City's boundaries, especially in characterizing Batik City and Batik's identity as Creative City. This condition is because the Gadjah Mada Street as an aspect of its edge elements both in design and completeness of the batik-nuanced attributes is still minimal. Therefore, the impression and popularity are not strong as the Loji River, which is part of the strategic object in characterizing Batik City image.

\section{4) Preservation elements}

The Batik Museum is strongly identified as representing the preservation element in forming Pekalongan's image as Batik City and Batik Creative City. However, approximately $84 \%$ of the local community respondents and 87 tourists stated that this object is a characteristic of Batik City's identity. Meanwhile, $87 \%$ of the local community respondents and $89 \%$ of tourists stated that it is used in characterizing the identity of Batik Creative City. Based on this observation, the Batik Museum displays an appropriate impression because of its status as a center for batik preservation of Indonesian cultural heritage. In fact, its existence is able to attract tourists, to either learn ways of producing batik, or investigate the culture.

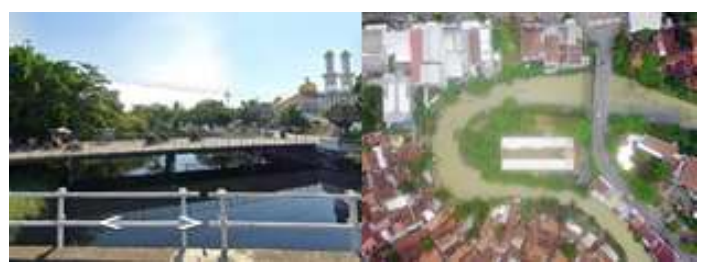

Figure 8. Existing condition of the Batik Museum object

Source: (Innayah 2018)

The existence of the Batik Museum has good popularity and impressive level compared to the Bugisan Batik Factory, an object in reflecting the identity of Batik and Creative City. Irrespective of the fact that the Bugisan Batik Factory is one of the largest and has a marketing coverage categorized on a foreign scale, it is less popular than the Batik Museum. This is because it is usually closed, in the sense that it is not opened to the public or tourists like the Batik Museum, which serves as the center for the Indonesian cultural batik preservation and is opened daily for tourist activities, therefore its popularity keeps increasing among members of the local community, tourists, and in cyberspace.

\section{5) Landmark element}

The landmark element strongly captured by the community as the main characteristic feature of Batik City is in the form of the World's City of Batik Monument. Approximately $76 \%$ of the local community respondents and $87 \%$ of tourists stated that this object is a characteristic of Batik City's identity. Meanwhile, in characterizing the Batik Creative City identity, $86 \%$ of the local community respondents and $80 \%$ of tourists mentioned the World's City of Batik Monument. Based on several respondents' confirmation, the World's City of Batik Monument is perceived to have a significant impression by a larger community. This is because its design resembles a traditional weaving machine that depicts that the local community's source of income is the batik weaving sector. Furthermore, the second reason is based on the fact that the name matches the city branding used by Pekalongan City.

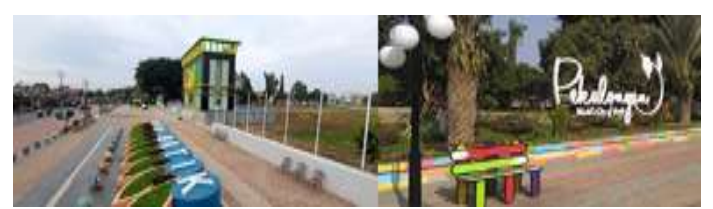

Figure 9. The Worls's City of batik monument object

Based on the existence of the World's City of Batik Monument, it has a good popularity and impressive level compared to Gapura Nusantara in characterizing Batik and Creative City's identity. This is because Gapura Nusantara, is a new icon in the public space, and is not yet widely known compared to the World's City of Batik Monument, which has become a tourism promotion icon for Batik City Pekalongan since 2014 after it was named as part of the Creative City Network by UNESCO.

\section{6) Open space element}

The community strongly considers this object to represent an open space element in characterizing Pekalongan's image as Batik City and Batik Creative City. In addition, $79 \%$ of the local community respondents and $69 \%$ of tourists stated that this object is a characteristic of Batik City's identity. Meanwhile, in characterizing the Batik Creative City identity, the square was 
mentioned $84 \%$ of the local community and $76 \%$ of tourists.

In accordance with the interviews conducted on several respondents, it was confirmed that Pekalongan Square exhibits an absolute impression on the larger community due to the nuances of street furniture and batik-patterned landmarks. Furthermore, parts of the square also act as public creative spaces that accommodate social, cultural, and environmental activities.

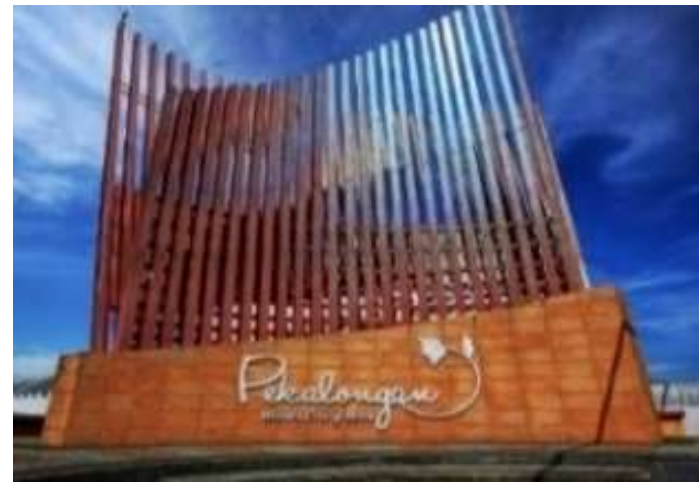

Figure 10. Object condition of Pekalongan City square

Pekalongan City Square's popularity level is quite impressive in characterizing the Batik and Creative City identity, compared to the Batik Jetayu Park. The lack of popularity is because its design facades do not maximally support the creation of creative spaces with batik nuances compared to the Pekalongan City Square, which is properly designed to support social and local cultural activities.

The results of this research show that the visual attributes and physical elements of Pekalongan City symbolize the batik industry's economic base activities. It also comprises of processes, transactions, and training regarded as important factors in forming the city's image. This is significant, especially when the physical elements are old enough, therefore it tends to have more historical value regarding the long tradition of the local community. In fact, it also causes these elements to support the city identity formation firmly. The long and distinctive traditional batik nuances, were not found in other cities, therefore it is perceived as an icon worth visiting, with documentations. Furthermore, this greatly supports tourism promotion. Therefore, the more visual documentation of these iconic elements, the stronger the city's identity is perceived by, the larger community. These findings are consistent with several previous studies carried out by Lestari (2016), Adona, Nita, and Mafrudoh (2017) and Ziyaee (2018). According to these studies, the essence of the branding process occurs through the creation of a distinctive city image, which is differentiated from other cities, thereby attracting tourists (Saputri, Fauzi, and Irawan 2018; d'Ovidio and Cossu 2017; Puspitasari 2016).

In the case of Pekalongan City, iconic distinctiveness strongly emerged through 4 physical elements, namely (1) preservation, (2) landmarks, (3) open spaces, and (4) districts. Preservation has a distinctive, impressive strength compared to the historical elements inherent in heritage objects such as the Batik Museum, which is also a cultural tourism destination. The landmark element has an impressive iconic distinctiveness derived from the city monuments according to the design compositions that contain batik nuances and acts as tourism promotion icons. Meanwhile, open space has a strong distinctiveness potential, which supports the development of creative spaces for the public. Meanwhile, district elements have a distinctive strength based on the existence of batik villages, which acts as centers for batik craftsmen as well as a pioneer for its formation.

The uniqueness of each physical element is an important potential in creating attractiveness and supporting urban branding. Irrespective of the empirical conditions of the aforementioned physical elements, occasionally, some tourists visit to witness the visual uniqueness of these elements or objects. Therefore, these conditions are consistent with the previous research carried out by Budiman, Rondonuwu, and Tungka (2018), which stated that the existence of a distinctive and visually unique physical component of the city is the main attraction element for tourists. Therefore, in the long term, its support also affects the city's way of life because the physical element's uniqueness tends to become the city's spirit and identity (Hilman and Megantari 2018).

\section{Conclusion}

In conclusion, the iconic design of the city's physical elements, which express or symbolize the unique creative economic base activities, support the city's image formation. This condition also serves as an opportunity to support the 
process of strengthening branding in creative cities. Therefore, the stronger the uniqueness of the city's visual image perceived through branding, the more influential the condition to increase tourist visits.

Meanwhile, increasing tourist visits also has the potential to increase the scale of the city's creative economy. This is because tourists always make a purchase either in the form of facilities or souvenirs. When this occurs massively, it also affects tourist demand for a unique tour service or a souvenir, thereby increasing the city's creative economic income.

\section{References}

Adona, Fitri, Sri Nita, and Luth Mafrudoh. 2017. 'City Branding: Strategi Pemasaran Pariwisata Kota Padang'. Seminar Nasional Multi Disiplin Ilmu \& Calll For Papers UNISBANK KE-3 (SENDI_U 33 (Sendi_U 3): 536-46. https://adoc.tips/city-brandingstrategi-pemasaran-pariwisata-kotapadang.html.

Anshori, Sultan. 2019. 'Denpasa Dinobatkan Sebagai Kota Kreatif Indonesia 2019'. Bisnis.Com. 2019. https://bali.bisnis.com/read/20191013/537/11 58454/denpasar-dinobatkan-sebagai-kotakreatif-indonesia-2019.

Bawole, Paulus. 2020. 'Pengembangan Kampung Kota Sebagai Salah Satu Alternatif Tujuan Wisata Minat Khusus'. ARTEKS: Jurnal Teknik Arsitektur 5 (1): 115-26. https://doi.org/10.30822/arteks.v5i1.362.

BPS. 2016. 'Launching Publikasi Ekonomi Kreatif 2016'. Jakarta. https://www.bps.go.id/news/2016/12/16/171/1 aunching-publikasi-ekonomi-kreatif2016.html.

Budiman, Ival Tom Rees, Dwight M. Rondonuwu, and Aristotulus E. Tungka. 2018. 'Analisis Elemen-Elemen Pembentuk Citra Kota Di Kawasan Perkotaan Tahuna, Kabupaten Kepulauan Sangihe'. Spasial 5 (2): 190-99. https://ejournal.unsrat.ac.id/index.php/spasial /article/view/20791/20482.

d'Ovidio, Marianna, and Alberto Cossu. 2017. 'Culture Is Reclaiming the Creative City: The Case of Macao in Milan, Italy'. City, Culture and Society 8 (March): 7-12. https://doi.org/10.1016/j.ccs.2016.04.001.

Departemen Perdagangan Republik Indonesia. 2008. 'Pengembangan Ekonomi Kreatif Indonesia 2025: Rencana Pengembangan Ekonomi Kreatif Indonesia 2009 - 2025'. Jakarta.

Hilman, Yusuf Adam, and Krisna Megantari. 2018. 'Model City Branding Sebagai Strategi Penguatan Pariwisata Lokal Provinsi Jawa Timur'. Jurnal Komunikasi Dan Kajian Media 2 (2). https://jurnal.untidar.ac.id/index.php/komuni kasi/article/view/784.

Innayah. 2018. 'Keruhnya Sungai Di Balik Cerahnya Batik Pekalongan'. KOMPAS.Com. 2018. https://www.kompasiana.com/innnayah/5bdf dfdcab12ae54227a3399/keruhnya-sungai-dibalik-cerahnya-batikpekalongan?page $=3 \&$ page_images $=1$.

Kemenparekraf. 2018. 'Upaya Pemerintah Meningkatkan Ekonomi Kreatif'. Jakarta. https://www.kemenparekraf.go.id/post/rencan a-strategis-2020-2024-

kemenparekrafbaparekraf.

Landry, Charles. 2006. The Art of City Making. 1st ed. United Kingdom: Routledge, Taylor and Francis Group.

Landry, Charles, and Franco Bianchini. 1995. The Creative City. London, United Kingdom: Demos.

https://www.demos.co.uk/files/thecreativecit y.pdf.

Latifah, L, and Maya Damayanti. 2016. 'Pariwisata Kreatif Berbasis Industri Batik Sebagai Upaya Pengembangan Ekonomi Lokal Kota Pekalongan'. TATALOKA 18 (1): 11. https://doi.org/10.14710/tataloka.18.1.1126.

Lestari, Retno Budi. 2016. 'Membangun Citra Sebuah Kota Dalam Persaingan Global Melalui City Branding'. Jurnal Ilmiah STIE MDP 5 (2): 68-79. http://forbiswira.stiemdp.ac.id/wpcontent/uploads/2016/05/Retno-Budi.pdf.

Lynch, Kevin. 1960. The Image of the City. Harvard-MI. United States: MIT Press.

Manisyah, Miranti. 2009. 'Kota Kreatif (Creative City): Penelusuran Terhadap Konsep Kota Kreatif Melalui Pengamatan Studi Kasus'. Universitas

Indonesia. 
https://lib.ui.ac.id/file?file=digital/20249511R050928.pdf.

Purbadi, Yohanes Djarot, and Reginaldo Christophori Lake. 2019. 'Konsep KampungWisata Sejahtera, Kreatif, Cerdas Dan Lestari Berkelanjutan'. EMARA: Indonesian Journal of Architecture 5 (1): 12-23. https://doi.org/10.29080/eija.v5i1.641.

Puspitasari, Cindy Putri. 2016. 'Strategi City Branding Kota Surakarta Melalui Instagram @agendasolo'.

UNIVERSITAS MUHAMMADIYAH SURAKARTA. http://eprints.ums.ac.id/54200/3/Naskah Publikasi.pdf.

Saputri, Amellia Fatimatus, Achmad Fauzi, and Ari Irawan. 2018. 'Pengaruh City Branding Terhadap City Image Dan Keputusan Berkunjung Ke Kota Wisata Batu'. Jurnal Administrasi Bisnis 54 (1): 82-91. http://administrasibisnis.studentjournal.ub.ac. id/index.php/jab/article/view/2220.

Sawe, Benjamin Elisha. 2017. 'UNESCO Creative Cities In South America'. WorldAtlas. https://www.worldatlas.com/articles/unescocreative-cities-in-south-america.html.

Shirvani, Hamid. 1985. The Urban Design Process. New York: Van Nostrand Reinhold Company.

Trancik, Roger. 1986. Finding Lost Space: Theories of Urban Design. Finding Lost Space. New York: John Wiley \& Sons Inc.

Ziyaee, Maryam. 2018. 'Assessment of Urban Identity through a Matrix of Cultural Landscapes'. Cities 74 (April): 21-31. https://doi.org/10.1016/j.cities.2017.10.021.

\section{Author(s) contribution}

Edy Abdurrahman Syahrir contributed to the research concepts preparation, methodologies, investigations, data analysis, visualization, articles drafting and revisions.

Retno Widodo Dwi Pramono contribute to the research concepts preparation and literature reviews, data analysis, of article drafts preparation and validation. 